\title{
PELAKSANAAN KLAIM PRODUK ASURANSI JP- ASTOR PADA PT. JASARAHARJA PUTERA CABANG PADANG
}

\author{
Insani, Ratna Widayati \\ Akademi Keuangan dan Perbankan Padang \\ ratnawidayati@akbpstie.ac.id
}

\begin{abstract}
Insurance has a very important role in providing certainty protection for people, both commercial and non commercial, insurance can provide protection in the form of education, health, old age, death and property. Which is a necessity of life that is not less important in this era of globalization is the need for insurance services. The definition of insurance under KUHD 246 states that "insurance or coverage is an agreement by which the insurer strikes himself to an insured, accepting a premium, for replacement to him for an event that is not certain".Insurance companies have excellent service quality in serving the Customer including in serving insurance claims, because the quality of this service will be a benchmark for customers if they will use the same service, including for service claims. "Insurance Claim is a claim from the insured party in connection with the existence of the contract between the insurance agreement with the insured person who each party bind themselves to guarantee payment of compensation by the insurer if the insurance premium payment has been made by the insured, when the accident happened suffered by the insured party ".
\end{abstract}

Keyword :Insurance, service, implementation, claim, product

\section{PENDAHULUAN}

Asuransi mempunyai peranan yang sangat penting dalam memberikan kepastian perlindungan bagi manusia, baik bersifat komersial maupun non komersial, asuransi dapat memberikan proteksi dalam bentuk pendidikan, kesehatan, hari tua, kematian maupun harta benda. Menurut KUHD 246 disebutkan bahwa "asuransi atau pertanggungan adalah suatu perjanjian dengan mana serang penanggung mengikatkan diri kepada seorang tertanggung, dengan menerima suatu premi, untuk penggantian kepadanya karena suatu peristiwa yang tidak tentu".

Asuransi di Indonesia sekarang ini mengalami peningkatan di setiap tahunnya sejalan dengan pemahaman asuransi dimasyarakat, masyarakat di Indonesia mulai memahami asuransi menjadi bagian dari kegiatan manajemen resiko yang 
memberikan jaminan dan proteksi terhadap harta benda, dan jiwa seseorang sehingga berdampak pada pertumbuhan industri asuransi secara umum.

Bisnis asuransi dilihat dari beberapa negara juga mengalami peningkatan yang cukup baik, walaupun pertumbuhan ekonomi dunia mulai melemah di tingkat global. Berdasarkan kenyataan tersebut, saat ini banyak bermunculan perusahaan-perusahaan asuransi termaksuk Indonesia yang menawarkan berbagai jenis polis dengan kebutuhan masyarakat, Salah satu perusahaan Asuransi yaitu PT. Jasaraharja Putera Cabang Padang memiliki produk unggulan yang sangat diminati oleh nasabah dan telah menjadi branding untuk produk sejenis kelasnya, yaitu produk Asuransi JP-ASTOR, yang merupakan produk asuransi yang tepat untuk melindungi kendaraan anda dari kerugian, kerusakan kebakaran atau peristiwa lain yang mungkin terjadi dimasa yang akan datang dan hal tersebut dijamin oleh polis (sesuatu perjanjian asuransi atau pertanggungan bersifat konsensual (adanya kesepakatan), harus dibuat secara tertulis dalam suatu akta antara pihak yang mengadakan perjanjian).

Perusahaan asuransi Jasaraharja Putera Cabang Padang memiliki kualitas pelayanan yang sangat baik dalam melayani Nasabah termasuk dalam melayani klaim asuransi, karena kualitas pelayanan jasa ini akan menjadi tolak ukur bagi pelanggan jika mereka akan menggunakan pelayanan yang sama.

Menurut (Budi, 2012) menyatakan bahwa "Klaim Asuransi adalah tuntutan dari pihak tertanggung sehubungan dengan adanya kontrak perjanjian antara asuransi dengan piak yang tertanggung yang masing-masing pihak mengikatkan diri untuk menjamin pembayaran ganti rugi oleh penanggung jika pembayaran premi asuransi telah dilakukan oleh pihak tertanggung, ketika terjadi musibah yang diderita oleh pihak teretanggung".

Dengan pelayanan yang baik, konsumen dapat memberikan feedback positif kepada perusahaan jasa berupa loyalitas dan keputusan pembelian berulang. Feedback positif sangat bermanfaat bagi perusahaan karena dapat meningkatkan keuntungan yang maksimal. Menurut (Kotler, 2008) "Pelayanan adalah setiap kegiatan yang menguntungkan dalam suatu kumpulan atau kesatuan dan menawarkan kepuasan meskipun hasilnya tidak terkait pada suatu produk secara fisik". Dengan demikian pelayanan sebuah aktivitas atas kegiatan tertentu yang bersifat menguntungkan antara kedua belah pihak yaitu si penyedia jasa dan penerima jasa dan akan memberikan kepuasan serta pemenuhan kebutuhan si penerima jasa.

Proses klaim sendiri ialah proses dimana konsumen meminta ganti rugi kepada perusahaan asuransi terhadap kejadian tak terduga yang telah dialaminya. Dengan mengumpulkan bukti-bukti yang ada dari konsumen dan bukti tersebut adalah benar, maka setelah itu perusahaan asuransi akan membayar ganti rugi terhadap konsumen yang melakukan klaim.

Dalam pelayanan klaim agar dapat memberikan pelayanan prima, maka petugas atau karyawan harus menerapkan pelayanan yang komunikatif dimana dalam pelayanan komunikatif tersebut petugas klaim harus terampil dalam berkomunikasi. Dengan begitu nasabah akan memahami maksud yang ingin disampaikan secara jelas dan meminimalisir komplain atau keluhan. Kecepatan dalam pelayanan juga dibutuhkan dalam penerapan pelayanan prima. Dengan 
kompetensi karyawan dalam memberikan pelayanan maka akan meningkat waktu penyelesaian, dimana proses pelayanan yang cepat dan tepat adalah hal utama yang harus diperhatikan dalam penyampaian jasa. Selain itu yang menjadi unsur penting dalam pelayanan adalah keramahan karyawan dalam menyampaikan layanannya. Karyawan harus berbicara dengan sopan dan ramah dalam memberikan pelayanan.

Dalam pengumpulan data dan bahan untuk pengumpulan data ini digunakan metode penelitian adalah Studi kepustakaan (Library Research)Penilaian yang dilakukan ke perpustakaan beberapa buku ilmiah dan tulisan-tulisan yang berhubungan dengan pembahasan yang dilakukan dan Studi Lapangan (Field Research)Peninjauan langsung ke objek lapangan penelitian dipilih untuk meneliti hasil data primer dan membantu penulis melengkapi data yang diperlukan. Adapun cara riset ini adalah dengan mewawancarai pihak-pihak yang berkepentingan dalam hal ini adalah perusahaan atau instansi yang terkait.

Teknik analisa data yang digunakan adalah dilakukan secara kualitatif, yaitu Data yang dinyatakan dalam bentuk kata-kata atau bukan dalam bentuk angka. Data ini biasanya menjelaskan karakteristik atau sifat, yang kemudian dibandingkan dengan teori yang diperoleh dari berbagai liteatur untuk selanjutnya ditarik kesimpulan.

Dalam menganalisa data penulis melakukan Teknik analisa data yang digunakan adalah dilakukan secara kualitatif, yaitu data yang dinyatakan dalam bentuk kata-kata atau bukan dalam bentuk angka. Data ini biasanya menjelaskan karakteristik atau sifat, yang kemudian dibandingkan dengan teori yang diperoleh dari berbagai liteatur untuk selanjutnya ditarik kesimpulan.

Tujuan dari penulisan tugas akhir ini adalah untuk mengetahui dan memahami bagaimana pelaksanaan klaim produk jasa asuransi pada PT. Jasaraharja Putera Cabang Padang, dan juga untuk mengetahui Pelayanan klaim produk jasa asuransi JP-ASTOR pada PT. Jasaraharja Putera Cabang Padang, dan sebagai alat untuk membandingkan antara teori yang penulis dapatkan di perkuliahan dengan pratek kerja lapangan. Memberikan pemahaman kepada pembaca mengenai pelayanan klaim produk jasaasuransi JP-ASTOR pada PT. Jasaraharja putera cabang Padang. Diharapkan dapat digunakan sebagai bahan pertimbangan dalam pelayanan klaim produk jasa asuransi JP-ASTOR pada PT. Jasaraharja Putera Cabang Padang dalam melakukan kinerja yang lebih baik.

\section{ANALISA DAN PEMBAHASAN Pengertian Asuransi}

Asuransi atau dalam bahasa Belanda "verzekering" berarti pertanggungan. Di asuransi terlibat dua pihak, yaitu yang sanggup menanggung atau menjamin, bahwa pihaktertanggung akanmendapat penggantian suatu kerugian, yang mungkin akan ia alami sebagai akibat dari suatu peristiwa yang semula belum tentu akanterjadi atau semula belum dapat ditentukan saat akan terjadinya.

Pengertian asuransi disebutkan dalam Pasal 246Tahun 1843 KUHD yang menentukan bahwa :"Asuransi atau pertanggungan adalah suatu perjanjian denganmana seseorang penanggung mengikatkan diri kepadatertanggung, dengan menerima suatu premi untuk memberikan penggantian kepadanya karena suatu 
kerugian,kerusakan atau kehilangan keuntungan yang diharapkan, yang mungkin akan dideritanya karena suatu peristiwa yang tak tertentu".

\section{Unsur-Unsur Asuransi}

Dalam Kitab Undang-undang Hukum Dagang (KUHD) Pasal 246 tentang, 3 (tiga) Unsur mutlak asuransi :

a. Adanya Kepentingan

b. Adanya Peristiwa Tak Tentu

c. Adanya Kerugian

Berdasarkan pasal 246 kitab Undang-undang Hukum Dagang (KUHD), dapat diuraikan unsur-unsur asuransi sebagai berikut:

1) Pihak-pihak

Pihak-pihak dalam asuransi yaitu penanggung dan tertanggung.

2) Status pihak-pihak

Penanggung harus berstatus perusahaan badan hukum, dapatberbentuk Perseroan Terbatas (PT), Koperasi atau usaha bersama.

3) Objek asuransi

Objek asuransi dapat berupa diri sendiri, benda, hak atau kepentingan yang melekat pada benda dan sejumlah uang yang disebut premi atau ganti rugi.

4) Peristiwa asuransi

Peristiwa asuransi adalah perbuatan hukum berupa persetujuan atau kesepakatan bebas antara penanggung dan tertanggung.

\section{Syarat Sah Perjanjian Asuransi}

KUH Perdata pasal 1320 menyebutkan bahwa ada 4 syarat sah suatu perjanjian, yaitu kesepakatan para pihak, kewenangan berbuat, objek tertentu dan kuasa yang halal, sedangkan syarat yang diatur dalam KUHD pasal 251 adalah:

1. Kesepakatan (consensus)

Pengadaan perjanjian antara tertanggung dan penanggung dapat dilakukan secara langsung atau secara tidak langsung.Dilakukan secara langsung artinya kedua belah pihak mengadakan perjanjian asuransi tanpa melalui perantara.

2. Kewenangan (authority)

Kedua pihak tertanggung dan penanggung wenang melakukan perbuatan hukum yang diakui oleh undang-undang.Kewenangan berbuat tersebut ada yang bersifat subjektif dan ada yang bersifat objektif.

3. Objek Tertentu (fixed object)

Objek tertentu dalam Perjanjian Asuransi adalah objek yang diasuransikan, dapat berupa harta kekayaan dan kepentingan yang melekat pada harta kekayaan dapat pula berupa jiwa atau raga manusia.

4. Kausa yang Halal (legal cause)

Kausa yang halal maksudnya adalah isi perjanjian asuransi itu tidak dilarang undang-undang, tidak bertentangan dengan ketertiban umum, dan tidak bertentangan dengan kesusilaan.

5. Pemberitahuan (notification)

Tertanggung wajib memberitahukan kepada penanggung mengenai keadaanobjek asuransi.Kewajiban ini dilakukan pada saat mengadakan asuransi. 


\section{Jenis-Jenis Asuransi}

Kitab Undang-Undang Hukum Dagang di dalam Pasal 247 menyebutkan penggolongan jenis asuransi meliputi:

1. Asuransi Kerugian Umum
a. Asuransi pengangkutan
b. Asuransi kebakaran
c. Asuransi kredit
d. Asuransi kendaraan bermotor

2. Asuransi Sejumlah Uang (Asuransi Jiwa)
a. Asuransi hari tua
b. Asuransi beasiswa
c. Asuransi sosial (Diselenggarakan oleh Pemerintah)
d. Asuransi kecelakaan
e. Asuransi korban lalu lintas

\section{Pengertian Polis}

Polis asuransi adalah suatu perjanjian asuransi atau pertanggungan yang bersifat konsensual (adanya kesepakatan, yang harus dibuat secara tertulis dalam suatu akta antara pihak yang mengadakan perjanjian).Jadi, polis adalah tanda bukti perjanjian pertanggungan yang merupakan bukti tertulis.

\section{Pengertian Premi}

Premi adalah sejumlah uang yang harus dibayarkan setiap bulannya sebagai kewajiban dari tertanggung atas keikutsertaannya di asuransi.Besarnya premi atas keikutsertaan di asuransi yang harus dibayarkan telah ditetapkan oleh perusahaan asuransi dengan memperhatikan keadaan-keadaan dari tertanggung.

Premi adalah salah satu unsur penting dalam asuransi karena merupakan kewajiban utama yang wajib dipenuhi oleh tertanggung kepada penanggung. Besarnya jumlah premi oleh tertanggung ditentukan berdasarkan penilaian risiko yang dipikul oleh penanggung. Premi asuransi merupakan syarat mutlak untuk menentukan perjanjian asuransi dilaksanakan atau tidak.

\section{Pengertian klaim}

Klaim Asuransi adalah Sebuah permintaan resmi kepada perusahaan asuransi, untuk meminta pembayaran akibat terjadinya resiko yang telah diperjanjikan tertanggung dan penanggung berdasarkan akta polis.

Menurut (Meiline, 2013) Definisi klaim menurut Ikatan Akuntan Indonesia yang terdapat dalam SAK No. 28 tahun 2009, tentang perusahaan asuransi kerugian, klaim adalah klaim yang jumlahnya telah disepakati, termaksuk biaya penyelesaian klaim. Secara garis besar, semua proses pembayaran yang dilakukan baik dalam pembayaran atas klaim asuransi maupun pembayaran uang muka, harus diikuti dengan prosedur yang telah ditentukan. Segala bentuk pembayaran yang dilakukan harus melibatkan 2 (dua) bagian keuangan dalam proses pembayaran, yaitu fungsi keuangan dan fungsi akuntansi. Fungsi keuangan bertugas untuk menjaga semua bukti tagihan dan melakukan pembayaran atas tagihan, sedangkan fungsi akuntansi hanya mencatat segala bentuk transaksi dan kegiatan keuangan pada buku harian dan membuat pembukuan. 
Jenis dan Produk yang ditawarkan PT. Jasaraharja Putera Cabang Padang

1. JP-BONDING

Merupakan suatu bentuk penjaminan antara pihak pemborong dengan PT. Jasaraharja Putera untuk mendapatkan pekerjaan yang biasa diminta oleh pihak pemilik proyek dengan maksud kesungguhan dari Principal dalam melaksanakan pekerjaannya sesuai kontrak yang telah disepakati.

2. JP-ASPRI (Asuransi Kecelakaan Pribadi)

Merupakan produk asuransi yang memberikan perlindungan terhadap kecelakaan pribadi.Produk asuransi ini melindungi nasabah dari kecelakaan dimana saja baik itu dirumah, ditempat kerja, atau dimanapun nasabah berada. JP-ASRI memberikan perlindungan dana asuransi untuk kecelakaan terhadap individu dari nasabah.

3. JP-ASKRED (Asuransi Kredit Perdagangan)

Produk asuransi JP-ASKRED merupakan asuransi yangmelindungi nasabah akibat resiko kerugian terhadap transaksi perdagangan yang biasanya terjadi dan dialami oleh pelaku usaha perdagangan,

4. JP-GRAHA

Merupakan produk asuransi yang menjamin aset bangunan serta harta benda yang ada didalamnya. JP-GRAHA melindungi dari kerugiaan dan kerusakan yang diakibatkan oleh kebakaran atau peristiwa lain yang mungkin terjadi dan menyangkut aset bangunan serta harta benda didalamnya.

5. JP-ASTOR (Asuransi Kendaraan Bermotor)

JP-Astor merupakan asuransi untuk menjamin kendaraan pribadi darinasabah PT. Jasaraharja Putera. Produk asuransi tersebut menjamin segala resiko kerusakan dan kehilangan dari kendaraan tersebut.

Dari jenis produk yang ditawarkan oleh PT. Jasaraharja Putera Cabang Padang diatas, penulis mengkhususkan kepada JP-ASTOR.

\section{Pengertian Premi JP-ASTOR}

Harga premi JP-ASTOR ditentukan berdasarkan kategori yang sudah ditentukan oleh perusahaan yang dikalikan dengan rate wilayah yaitu, (Wilayah 1 Sumatera, Wilayah 2 Jawa Barat, Wilayah 3 Jawa Timur) dan jenis dari pertanggungan yaitu :

A. Pertanggungan Comprehensive

Pertanggungan yang menawarkan pada kerusakan kendaraan secara keseluruhan kerugian yang dialami, yang biasanya disebut All Risk. Cakupan Pertanggungan sangat luas yaitu dengan adanya perluasan perlindungan seperti bencana alam, huru-hara, tanggung jawab pihak ketiga dan lainnya.

B. Pertanggungan Total Loss Only (TLO)

Merupakan pertanggungan yang menawarkan perlindungan pada kerusakan kendaraan minimal $75 \%$ dan klaim akan dibayarkan keseluruhan pada kerusakan kendaraan yang dialami.Jika kerusakan yang terjadi masih dibawah angka $75 \%$ pemilik kendaraan tidak bias mengajukan klaim untuk pertanggungannya, missal spion yang patah, atau 
hilang, baret-baret, penyok kecil dan kerusakan kecil lainnya akibat kecelakaan.

Tarif premi dan contoh perhitungan harga premi dapat dilihat sebagai berikut :

Tabel. 1

Tarif Premi atau Kontribusi pada Asuransi Kendaraan Bermotor

A. Pertanggungan Comprehensive

\begin{tabular}{|c|c|c|c|c|c|c|c|}
\hline \multirow[t]{2}{*}{ Kategori } & \multirow{2}{*}{$\begin{array}{c}\text { Uang } \\
\text { Pertanggungan }\end{array}$} & \multicolumn{2}{|c|}{ Wilayah 1} & \multicolumn{2}{|c|}{ Wilayah 2} & \multicolumn{2}{|c|}{ Wilayah 3} \\
\hline & & $\begin{array}{r}\text { Batas } \\
\text { Bawah }\end{array}$ & Batas Atas & $\begin{array}{c}\text { Batas } \\
\text { Bawah }\end{array}$ & Batas Atas & $\begin{array}{c}\text { Batas } \\
\text { Bawah }\end{array}$ & $\begin{array}{r}\text { Batas } \\
\text { Atas }\end{array}$ \\
\hline \multicolumn{8}{|c|}{ Jenis Kendaraan Non Bus dan Non Truk } \\
\hline Kategori 1 & $\begin{array}{l}0 \text { s.d Rp. } \\
125.000 .000\end{array}$ & $3,82 \%$ & $4,20 \%$ & $3,44 \%$ & $3,78 \%$ & $2,53 \%$ & $2,78 \%$ \\
\hline Kategori 2 & $\begin{array}{l}\text { >Rp. } 125.000 .000 \\
\text { s.d Rp. } 200.000 .000\end{array}$ & $2,67 \%$ & $2,94 \%$ & $2,47 \%$ & $2,72 \%$ & $2,07 \%$ & $2,28 \%$ \\
\hline Kategori 3 & $\begin{array}{l}>\mathrm{Rp} 200.000 .000 \\
\text { s.d Rp.400.000.000 }\end{array}$ & $1,71 \%$ & $1,88 \%$ & $1,71 \%$ & $1,88 \%$ & $1,40 \%$ & $1,54 \%$ \\
\hline Kategori 4 & $\begin{array}{l}>\text { Rp. } 400.000 .000 \\
\text { s.d Rp. } 800.000 .000\end{array}$ & $1,20 \%$ & $1,32 \%$ & $1,20 \%$ & $1,32 \%$ & $1,20 \%$ & $1,32 \%$ \\
\hline Kategori 5 & >Rp. 800.000 .000 & $1,05 \%$ & $1,16 \%$ & $1,05 \%$ & $1,16 \%$ & $1,05 \%$ & $1,16 \%$ \\
\hline \multicolumn{8}{|c|}{ Jenis Kendaraan Roda 2 (dua) } \\
\hline Kategori 6 & $\begin{array}{c}\text { Semua uang } \\
\text { pertanggungan }\end{array}$ & $2,11 \%$ & $2,32 \%$ & $2,11 \%$ & $2,32 \%$ & $2,11 \%$ & $2,32 \%$ \\
\hline
\end{tabular}


Tabel. 2

\section{B. Pertanggungan Total Loss Only}

\begin{tabular}{|c|c|c|c|c|c|c|c|}
\hline \multirow[t]{2}{*}{ Kategori } & \multirow{2}{*}{$\begin{array}{c}\text { Uang } \\
\text { Pertanggungan }\end{array}$} & \multicolumn{2}{|c|}{ Wilayah 1} & \multicolumn{2}{|c|}{ Wilayah 2} & \multicolumn{2}{|c|}{ Wilayah 3} \\
\hline & & $\begin{array}{c}\text { Batas } \\
\text { Bawah }\end{array}$ & $\begin{array}{r}\text { Batas } \\
\text { Atas }\end{array}$ & $\begin{array}{l}\text { Batas } \\
\text { Bawah }\end{array}$ & $\begin{array}{l}\text { Batas } \\
\text { Atas }\end{array}$ & $\begin{array}{c}\text { Batas } \\
\text { Bawah }\end{array}$ & Batas Atas \\
\hline \multicolumn{8}{|c|}{ Jenis Kendaraan Non Bus dan Non Ttuk } \\
\hline Kategori 1 & $\begin{array}{l}0 \text { s.d Rp. } \\
125.000 .000\end{array}$ & $0,47 \%$ & $0,56 \%$ & $0,65 \%$ & $0,78 \%$ & $0,36 \%$ & $0,43 \%$ \\
\hline Kategori 2 & $\begin{array}{l}>\text { Rp. } 125.000 .000 \\
\text { s.d Rp. } 200.000 .000\end{array}$ & $0,44 \%$ & $0,53 \%$ & $0,44 \%$ & $0,53 \%$ & $0,31 \%$ & $0,37 \%$ \\
\hline Kategori 3 & $\begin{array}{l}>\text { Rp200.000.000 s.d } \\
\text { Rp.400.000.000 }\end{array}$ & $0,29 \%$ & $0,35 \%$ & $0,29 \%$ & $0,35 \%$ & $0,29 \%$ & $0,35 \%$ \\
\hline Kategori 4 & $\begin{array}{l}>\text { Rp. } 400.000 .000 \\
\text { s.d Rp. } 800.000 .000\end{array}$ & $0,25 \%$ & $0,30 \%$ & $0,25 \%$ & $0,30 \%$ & $0,25 \%$ & $0,30 \%$ \\
\hline Kategori 5 & $>$ Rp. 800.000 .000 & $0,20 \%$ & $1,24 \%$ & $0,20 \%$ & $0,24 \%$ & $0,20 \%$ & $0,24 \%$ \\
\hline Jenis Kenda & an Roda 2 (dua) & & & & & & \\
\hline Kategori 6 & $\begin{array}{l}\text { Semua uang } \\
\text { pertanggungn }\end{array}$ & $1,76 \%$ & $2,11 \%$ & $1,80 \%$ & $2,16 \%$ & $0,67 \%$ & $0,80 \%$ \\
\hline
\end{tabular}

\section{Perhitungan Premi}

Uang Pertanggungan $\mathrm{x}$ Rate $=$ Premi

Rp. 100.000.000 x 2,53\% (batas bawah wilayah 3 ) $=\underline{\mathbf{R p . ~ 2 . 5 3 0 . 0 0 0}}$

Pada awal pembayaran premi nasabah akan dikenakan biaya administrasi antara lain :

Biaya Polis : Rp. 10.000,-

Biaya Materai : Rp. 12.000,-

Jadi, Premi awal yang harus dibayarkan nasabah adalah :

Biaya Polis + Biaya Materai + Harga Premi $=$ Premi awal yang dibayarkan:

Rp. $10.000+$ Rp. $12.000+$ Rp. $2.530 .000=\underline{\text { Rp. 2.550.000 }}$

\section{Pengertian Klaim}

Klaim (Permohonan atau pengajuan kerugian konsumen) yang diterima PT. Jasaraharja Putera Cabang Padang adalah klaim asuransi yang perlindungan resikonya tertera dengan jelas dalam polis, dan melalui alur prosedur klaim sebagai berikut : 
Alur prosedur klaim sebagai berikut:

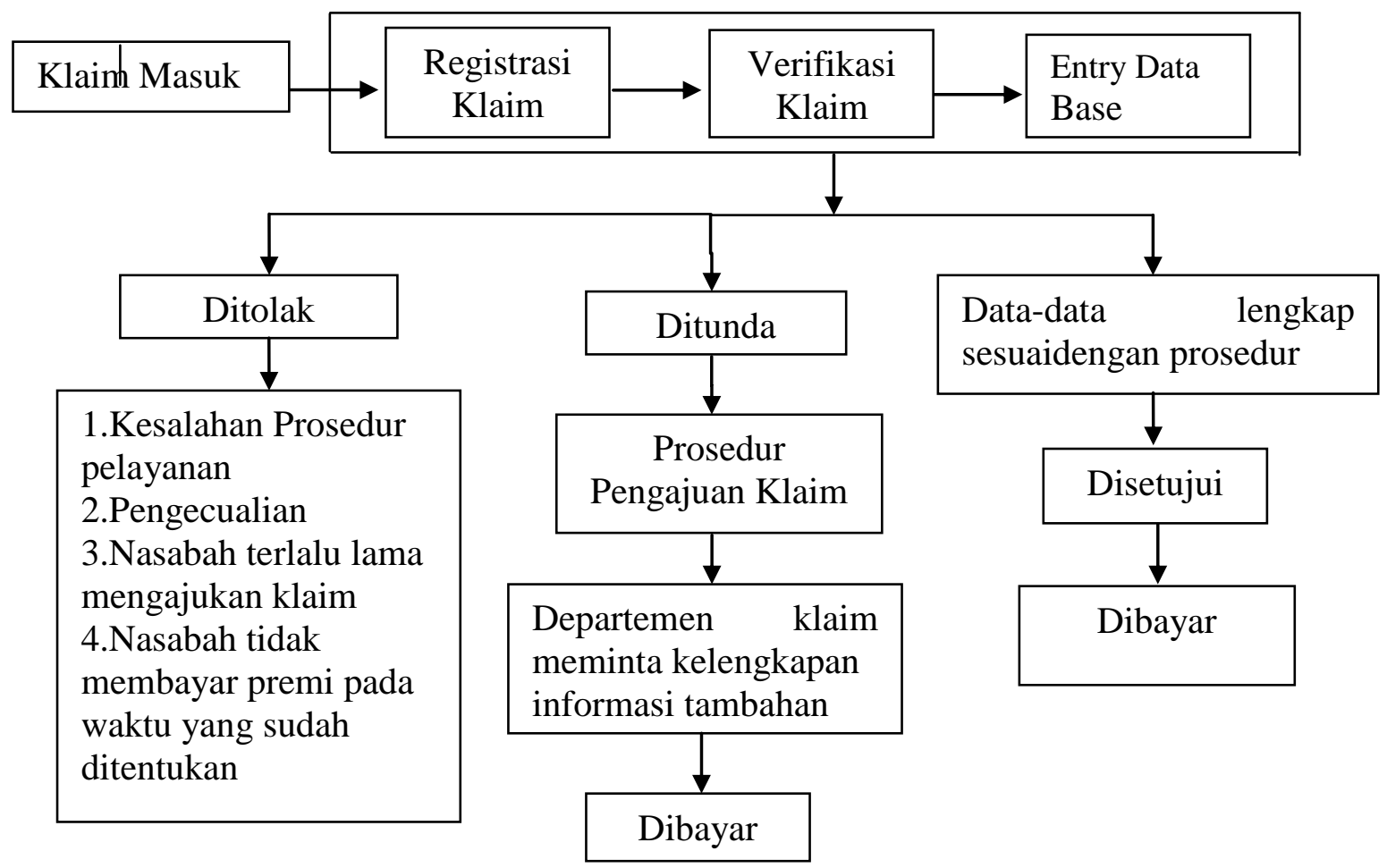

Alur klaim diatas menunjukkan bahwa klaim yang diajukan tidak selalu dibayarkan, karena data yang sudah dimasukan kedalam system akan diperiksa oleh petugas klaim terlebih dahulu, apakah klaim tersebut ditolak, ditunda atau dibayarkan.

1. Klaim ditolak

a. Kesalahan Prosedurpelayanan

b. Pengecualian

c. Setelah diperiksa adanya data yang kurang valid atau bersifat mengada-ada dari nasabah dan kurangnya data yang diperlukan.

d. Nasabah terlalu lama mengajukan klaim

Pengajuan klaim juga mempunyai batas yang telah ditentukan JP-

ASTOR yaitu, terhitung 8 (delapan hari) sejak terjadinya resiko.

e. Nasabah tidak membayar premi pada waktuu yang sudah ditentukan.

2. Klaim ditunda

a. Prosedur pengajuan klaim yang kurang tepat

b. Departemen klaim meminta kelengkapan tambahan surat-surat dari kepolisian, jika terjadi kecelakaan.

c. Disetujui

d. Setelah kelengkapan terpenuhi klaim akan dibayarkan kepada nasabah

3. Klaim dibayarkan

a. Data-data lengkap

b. Disetujui pimpinan

c. Dibayarkan 
Apabila klaim disetujui, perusahaan asuransi akan langsung membayarkan kerugian yang diterima oleh nasabah. Jika klaim tersebut ditunda, maka perusahaan asuransi akan meminta nasabah untuk melengkapi berkas-berkas yang kurang saat pengajuan klaim. Namun jika klaim ditolak, perusahaan tidak akan membayar uang ganti rugi.

\section{SIMPULAN}

Pelaksanaan klaim Asuransi JP-ASTOR pada PT. Jasaraharja Putera Cabang Padang mudah dicairkan melalui prosedur yang telah diatur dan ditentukan sehingga tidak memakan waktu lama dan tidak memberatkan nasabah yang mengajukan klaim.

\section{UCAPAN TERIMAKASIH}

Alhamdulillahirabbil'alamin, segala puji bagi Allah SWT pencipta seluruh alam semesta yang telah memberikan rahmat dan hidayah-Nya, sehingga penulis mampu menyelesaikan penelitian ini, sebagai salah satu syarat untuk memperoleh gelar Diploma III (Amd) . Penulis menyadari bahwa dalam penyelesaian artikel ini masih terdapat banyak kesalahan dan kekurangan, akan tetapi semoga segala usaha yang telah dilakukan dapat bermanfaat bagi semua, sebagai ilmu yang bermanfaat dan barokah.

Penulis juga menyadari bahwa selama berlangsungnya penelitian, penyusunan sampai pada tahap penyelesaian penulisan artikel ini tak lepas dari dukungan serta bantuan berbagai pihak. Oleh karena itu teriring do'a dan ucapan terima kasih penulis sampaikan kepada: 1) Kedua orang tua serta saudarasaudaraku tercinta yang telah memberikan nasihat, do'a, dan dukungan moril maupun materil untuk penulis dalam menuntut ilmu, sehingga penyusunan tugas akhir ini dapat terselesaikan.2) Ibu Afriyeni,SE. MM selaku Direktur Akademi Keuangan Dan Perbankan "Pembangunan"Padang. 3) Bapak Doni Marlius,SE. MM selaku ketua Prodi Akademi Keuangan Dan Perbankan "Pembangunan". 4) $\mathrm{Hj}$. Ratna Widayati,SH. MH selaku dosen pembimbing yang telah membimbing penulis dalam menyelesaikan tugas akhir ini. 5) Segenap dosen Jurusan Keuangan dan Perbankan atas segala ilmu dan bimbingannya. 6) Teman-teman angkatan 2015 yang telah saling memotivasi dan membantu terselesainya tugas akhir ini. 7) Seluruh pihak yang tidak bisa penulis sebutkan satu persatu.Semoga tugas akhir ini dapat bermanfaat dan ilmu pengetahuan. Amin yaa robbal alamiin.

\section{DAFTAR PUSTAKA}

Annisa. (2009). Program studi diploma 3 manajemen pemasaran fakultas ekonomi universitas negeri sebelas maret. Strategi Pemasaran Asuransi Jp-Astor Pada PT. Jasaraharja Putera Surakarta, 1(1), xxi.

Marlius, D. (2018). Loyalitas Nasabah Bank Nagari Syariah Cabang Bukittinggi Dilihat Dari Kualitas Pelayanan. Jurnal Pundi. Volume 1. No. 3. Hal.12-22. https://doi.org/10.31575/jp.v1i3.60 
Marlius, D. (2018). Pengaruh Dimensi Kualitas Pelayanan Website Akademik Terhadap Kepuasan Mahasiswa Pada STIE "KBP". Jurnal Ipteks Terapan. Volume 12. No. 2. Hal. 116-128. http://doi.org/10.22216/jit.2018.v12i2.633

Meiline. (2013). Fakultas Ekonomi Jurusan Akuntansi Universitas Sam Ratulangi Manado. Evaluasi Sistem Dan Prosedur Akuntansi Atas Pembayaran Klaim Asuransi Kesehatan Pada PT. Askes (Persero), 1(3), 331-338.

Kotler, Philip (2006). Manajemen Pemasaran, Edisi Pertama. Indonesia: PT. Indeks Kelompok Gramedia.

Tiza, M. F., \& Susanti, F. (2019). Pengaruh Kualitas Pelayanan Terhadap Kepuasan Pelanggan, Studi kasus pada perusahaan JNE Cabang Padang. https://doi.org/10.31227/osf.io/hx87m

Tjiptono, Fandy. 2008. Service Manajemen: Mewujudkan Layanan Prima. Yogyakarta: Andi. 